\title{
A novel polysaccharide derived from algae extract inhibits cancer progression via JNK, not via the p38 MAPK signaling pathway
}

\author{
PEIYU XIE ${ }^{1,2}$, FUKUKO HORIO ${ }^{1}$, ISAO FUJII ${ }^{1}$, JIEN ZHAO ${ }^{3}$, \\ MAKOTO SHINOHARA $^{3}$ and MAKOTO MATSUKURA ${ }^{1}$
}

${ }^{1}$ Laboratory of Clinical Pharmacology and Therapeutics, Faculty of Pharmaceutical Sciences, Sojo University, Kumamoto,
Kumamoto 860-0822; ${ }^{2}$ Department of Molecular Genetics, Graduate School of Medical Sciences, Kumamoto University,
Kumamoto, Kumamoto 860-8556; ${ }^{3}$ Ashikita Institution for Developmental Disabilities, Ashikita, Kumamoto 869-541, Japan

Received October 5, 2017; Accepted February 6, 2018

DOI: $10.3892 /$ ijo.2018.4297

\begin{abstract}
Cancer has long been one of the most malignant diseases worldwide. Processes in cancer cells are often mediated by Jun N-terminal kinase (JNK), p38 mitogen-activated protein kinase (p38 MAPK) and other signaling pathways. Traditional therapies are often problematic. Recently, a novel polysaccharide derived from algae extract was investigated due to the increasing interest in biological activities of compounds from marine organisms. The effect of this novel polysaccharide on human MKN45 gastric carcinoma cells was determined previously. The current aimed to determine whether the polysaccharide affects other types of cancer, and the deeper mechanisms involved in the process. Human MCF-7 breast cancer cells were used to investigate the novel polysaccharide for its role in the cell growth and migration, and determine the mechanisms affected. MTT assay, nuclear staining and fluorescence activated cell sorting analysis demonstrated that the novel polysaccharide reduced the viability of MCF-7 cells by inducing cell apoptosis and arresting the cells at G2/M phase. Results of western blot analysis demonstrated that phosphorylation of JNK and expression of p53, caspase- 9 and caspase- 3 were upregulated in the polysaccharide-treated MCF-7 cells. SP600125, an inhibitor of JNK, maintained MCF-7 cell viability, prevented cell apoptosis and cycle arrest, and downregulated the polysaccharide-induced protein phosphorylation/expression. However, a migration assay demonstrated that the novel polysaccharide did not change the migration of MCF-7 cells, as well as the expression of p38 MAPK, and matrix metalloproteinase- 9 and -2 . Taken together, the current
\end{abstract}

Correspondence to: Professor Makoto Matsukura, Laboratory of Clinical Pharmacology and Therapeutics, Faculty of Pharmaceutical Sciences, Sojo University, 4-22-1 Ikeda, Kumamoto, Kumamoto 860-0822, Japan

E-mail:mtmk@ph.sojo-u.ac.jp

Key words: MCF-7 cells, proliferation, apoptosis, cell cycle, Jun $\mathrm{N}$-terminal kinase, p38 mitogen-activated protein kinase study demonstrated that the novel polysaccharide suppressed cancer cell growth, induced cancer cell apoptosis and cell cycle arrest via JNK signaling, but had no effect on cancer cell migration and p38 MAPK signaling.

\section{Introduction}

Cancer has long been one of the most malignant diseases and a leading cause of mortality, worldwide (1). In recent years, with the accelerated pace of life, the deterioration of the environment and the increased work pressures, the incidence of cancer increase year by year (2). In the past, surgery and radiotherapy has been the most common treatment method (3). Although there is now a new era of molecular targeted therapy, these traditional therapies often bring numerous unwanted side effects and problems, and do not always improve the symptoms (4). Due to the limited efficacy traditional therapeutics, it is important to identify novel treatment strategies with reduced side effects.

In recent years, in Japan and worldwide, the interest in the biological activities of compounds from marine organisms is increasing (5). Various compounds with biological activities have been investigated and several have been developed into herbal medicines that are commercially available (6). A novel polysaccharide derived from algae extract has been previously investigated. The biological activity of this novel polysaccharide was first investigated using retinal pigment epithelial cells (7), and the effect in inhibiting human gastric carcinoma MKN45 cells was also reported recently (8). The current study aimed to determine if this extract affects other types of cancers, and the signaling pathways involved. Human MCF-7 breast cancer cells were used to investigate the effect of the novel polysaccharide on MCF-7 proliferation and migration, and determine the mechanisms involved in the process.

Abnormal proliferation and migration are critical physiological processes for cancer cell invasion (9). Induction of cell apoptosis is a useful mechanism to inhibit cell proliferation (10). In addition to apoptosis, cell cycle arrest is another cause of proliferation inhibition (11). It is well established that mitogen-activated protein kinase (MAPK) signaling pathways are involved in cell cycle, proliferation and migration (12). Jun N-terminal kinase (JNK), a member of MAPK 
family, is associated with cell proliferation inhibition (13). Phosphorylation of JNK activates downstream tumor suppressors, p53, caspase-9 and caspase-3, followed by apoptosis and cell cycle arrest (14). p38 MAPK, another member of MAPK family, increases matrix metalloproteinase-9 (MMP-9)/ MMP-2 activity and induces cell migration (15).

Based on the conclusions of our previous experiments using MKN45 cells (8), in the current study, MCF-7 cells were used to investigate the effect of the novel polysaccharide on the development of cancer, and to understand the mechanisms involved in the processes. The novel polysaccharide derived from algae extract suppressed MCF-7 cell proliferation by inducing apoptosis and cell cycle arrest, and activating the JNK signal pathway involving p53, caspase-9 and caspase-3. By contrast, this polysaccharide did not affect migration and did not change p38 MAPK signaling and the downstream MMP-9/MMP-2.

\section{Materials and methods}

Preparation of the novel polysaccharide. The novel polysaccharide was obtained from Toyo Medicine Institute (Ashikita, Japan). The novel polysaccharide was extracted from a type of Phaeophyceae (Sargassum), which is rich in hydrion and sulfate. The structure (Fig. 1) of the novel polysaccharide is modified by sulfate and phosphate groups (represented by R), with a typical sugar chain made of polymeride of disaccharides. According to the method described previously $(16,17)$, the novel polysaccharide was extracted using chloroform, ethyl acetate and n-butyl alcohol. Following isolation by column chromatography on silica gel and Sephadex LH-20 columns (GE Healthcare Bio-Sciences, Pittsburgh, PA, USA), polysaccharide was purified on a macroporous absorption resin column, and then sulfonated by sulfuric acid. The molecular weight of the polysaccharide was 11680 . The molecular weight was used for calculation of molar concentration $(\mu \mathrm{M})(18)$.

Cell culture. MCF-7 cells expressing the fluorescent ubiquitination-based cell cycle indicator(Fucci) probes (MCF-7-Fuccicells) were purchased from RIKEN BioResource Center (Tsukuba, Japan). MCF-7-Fucci cells were cultured in RPMI-1640 medium supplemented with $10 \%$ fetal bovine serum (FBS) and antibiotics (100 U/ml penicillin and $100 \mathrm{mg} / \mathrm{ml}$ streptomycin) (all from Sigma-Aldrich; Merck KGaA, Darmstadt, Germany). HeLa cells (RIKEN BioResource Center) were cultured in Dulbecco's modified Eagle's medium (Sigma-Aldrich; Merck KGaA) supplemented with $10 \%$ FBS, $100 \mathrm{U} / \mathrm{ml}$ penicillin and $100 \mathrm{mg} / \mathrm{ml}$ streptomycin. MCF-7 cells and HeLa cells were incubated in $5 \% \mathrm{CO}_{2}$ at $37^{\circ} \mathrm{C}$ for all experiments.

MTT assay. Following pretreatment with SP600125 $(5 \mu \mathrm{M})$ for $1 \mathrm{~h}$ or no treatment, MCF-7 cells or HeLa cells were plated at a density of $5 \times 10^{3}$ cells/well in a 96-well plate and exposed to polysaccharide $(100 \mu \mathrm{g} / \mathrm{ml})$ for $48 \mathrm{~h}$. According to the method described by Yuan et al (19), the viability of cells was determined by a colorimetric MTT assay. Absorbance at 550 and $690 \mathrm{~nm}$ was determined by an MTP-800 microplate reader (Corona Electric, Co., Ltd., Tokyo, Japan). The percentage of viable cell number was calculated as: Optical density (OD) of treated sample/OD of untreated control cells x100.
Fluorescence activated cell sorting (FACS) analysis. MCF-7 cells were incubated in a 6 -well plate $\left(1 \times 10^{5}\right.$ cells/well $)$ in RPMI medium. After treatment with the polysaccharide $(100 \mu \mathrm{g} / \mathrm{ml})$ for another $48 \mathrm{~h}, \mathrm{MCF}-7$ cells were washed twice with PBS (Sigma-Aldrich; Merck KGaA). To detect the apoptosis of cell, 10,000 individual cells were collected for each sample and Annexin V-Biotin Apoptosis kit was used following the manufacturer's instructions (BioVision, Inc., Milpitas, CA, USA). Apoptotic cells were analyzed using a FACSCalibur ${ }^{\mathrm{TM}}$ flow cytometer (BD Biosciences, San Jose, CA, USA) with CellQuest software (version 6.1; BD Biosciences).

Cell cycle analysis. Cell cycle analysis was performed by flow cytometry using a FACSCalibur ${ }^{\mathrm{TM}}$ and CellQuest software, as previously described (20). Briefly,MCF-7 cells ( $1 \times 10^{5}$ cells/well) were exposed to polysaccharide $(100 \mu \mathrm{g} / \mathrm{ml})$ for $48 \mathrm{~h}$, washed and re-suspended in PBS $(420 \mu \mathrm{l})$ following trypsinization and fixed in $99 \%$ ethanol at $-20^{\circ} \mathrm{C}$ for $2 \mathrm{~h}$. Subsequently, samples were incubated in $50 \mu 110 \mathrm{mg} / \mathrm{ml}$ RNase A (Sigma-Aldrich; Merck $\mathrm{KGaA}$ ) at $37^{\circ} \mathrm{C}$ for $30 \mathrm{~min}$, and then incubated with propidium iodide (20 $\mu \mathrm{l} 0.2 \mathrm{mg} / \mathrm{ml}$ solution) at room temperature for another $10 \mathrm{~min}$. Subsequently, DNA content was evaluated by FACS.

Nuclear staining. MCF-7 cells or HeLa cells were cultured in 6 -well plates $\left(1 \times 10^{5}\right.$ cells/well $)$ for $24 \mathrm{~h}$. Following treatment with the polysaccharide $(100 \mu \mathrm{g} / \mathrm{ml})$ for another $48 \mathrm{~h}$, cells were washed with PBS, and fixed in $4 \%$ paraformaldehyde (Sigma-Aldrich; Merck KGaA) for $30 \mathrm{~min}$. Cells were stained with Hoechst $33342(20 \mathrm{mg} / \mathrm{ml})$ at room temperature in the dark for $15 \mathrm{~min}$. Then cell morphological changes were assessed by fluorescence microscopy.

Fucci system. MCF-7 cells were plated at a density of $1 \times 10^{5}$ cells/well in a 6 -well plate and treated with polysaccharide $(100 \mu \mathrm{g} / \mathrm{ml})$ for $48 \mathrm{~h}$. The MCF-7 cells used expressed two Fucci probes, emitting red fluorescence $\left(\mathrm{SCF}^{\mathrm{Skp} 2}\right)$ in $\mathrm{G} 1 / \mathrm{G} 0$ phase and green fluorescence (APC ${ }^{\mathrm{Cdh} 1}$ ) in $\mathrm{S} / \mathrm{G} 2 / \mathrm{M}$ phases (21). A FV10i-DOC confocal laser-scanning microscope with a UPLSAPO x60 Wobjective lens (Olympus Corporation, Tokyo, Japan) was used to observe the cellular fluorescence and obtain phase contrast images as previously described (22).

Migration assay. A 48-well chamber migration assay kit with polycarbonate membrane (Whatman ${ }^{\circledR}$ Nuclepore $^{\mathrm{TM}}$; Sigma-Aldrich; Merck KGaA) was used for a migration assay according to the method previously described (23). Briefly, the upper wells were coated with $0.01 \%$ collagen for $30 \mathrm{~min}$ at $37^{\circ} \mathrm{C}$. MCF-7 cells were treated with polysaccharide $(100 \mu \mathrm{g} / \mathrm{ml})$ for $48 \mathrm{~h}$ at $37^{\circ} \mathrm{C}$, then MCF-7 cells $\left(5 \times 10^{4}\right.$ cells/well) were seeded on the upper chamber of the Transwell in serum-free RPMI medium. As chemotactic medium, RPMI containing $10 \%$ fetal calf serum (Sigma-Aldrich; Merck KGaA) was added to the lower wells. After $24 \mathrm{~h}$ at $37^{\circ} \mathrm{C}$, the cells that migrated towards to the lower filter surface were fixed with $4 \%$ paraformaldehyde for $10 \mathrm{~min}$ at room temperature and then stained with crystal violet for $10 \mathrm{~min}$ at room temperature. The number of migrated cells was counted under a X100 microscope (Olympus Optical, Co., Ltd., Tokyo, Japan). 

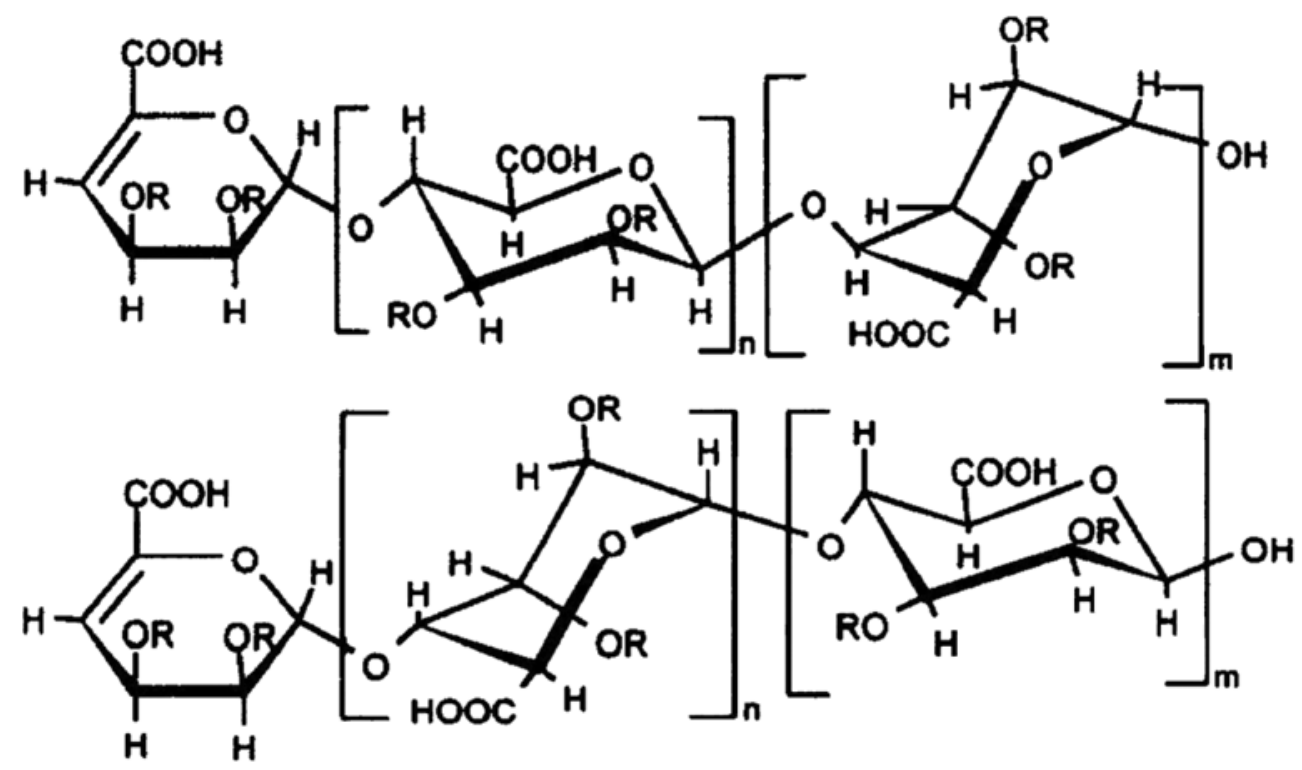

Figure 1. Molecular structure of the novel polysaccharide. The novel polysaccharide is modified by sulfate and phosphate groups (represented by R).

Reverse transcription-quantitative polymerase chain reaction $(R T-q P C R)$. MCF-7 cells were treated with TRIzol reagent (Life Technologies; Thermo Fisher Scientific, Inc.) for 2-3 min to completely dissolve cells. Total RNA was extracted from MCF-7 cells. RT was performed using a Transcriptor First Strand cDNA Synthesis kit (Roche Applied Science, Madison, WI, USA), with incubation at $37^{\circ} \mathrm{C}$ for $20 \mathrm{~min}$, then $75^{\circ} \mathrm{C}$ for $10 \mathrm{~min}$. The relative mRNA quantification was performed by ABI 7300 Fast real-time PCR system (Applied Biosystems, Foster City, CA, USA) and normalized to GAPDH. SYBR Premix Ex Taq II (Takara Bio, Inc., Otsu, Japan) was used and the thermocycling conditions were: $95^{\circ} \mathrm{C}$ for $30 \mathrm{sec}$ for pre-denaturation, then 40 cycles of $95^{\circ} \mathrm{C}$ for $3 \mathrm{sec}$ for denaturation, $60^{\circ} \mathrm{C}$ for $31 \mathrm{sec}$ for annealing and $72^{\circ} \mathrm{C}$ for $60 \mathrm{sec}$ for elongation, and finally $72^{\circ} \mathrm{C}$ for $5 \mathrm{~min}$ for re-elongation. RT-qPCR results were analyzed by $2^{-\Delta \Delta \mathrm{Cq}}$ method described by Livak and Schmittgen (24). Certified ${ }^{\mathrm{TM}}$ PCR Agarose (Bio-Rad Laboratories, Inc., Hercules, CA, USA) and ethidium bromide (Sigma-Aldrich; Merck KGaA) staining were used to separate PCR products. The following primers (Hokkaido System Science Co., Ltd., Sapporo, Japan) were used: MMP-9, forward, 5'-CTTCACTTTCCTGGGTAAG-3' and reverse, 5'-CACTTCTTGTCGCTGTCAAA-3'; MMP-2, forward, 5'-GACATACATCTTTGCTGGAGAC-3' and reverse, 5'-TTCAGGTAATAGGCACCCTT-3'; and GAPDH, forward, 5'-TGCACCACCAACTGCTTAGC-3' and reverse, 5'-GGCATG GACTGTGGTCATGAG-3'.

Gelatin zymography. MCF-7 cells $\left(1 \times 10^{5}\right.$ cells/well) were pretreated with $100 \mu \mathrm{g} / \mathrm{ml}$ polysaccharide in RPMI medium for $48 \mathrm{~h}$. As described previously (25), supernatants of culture medium of MCF-7 cells $(10 \mu \mathrm{l})$ were collected and subjected to electrophoresis (10\% SDS-polyacrylamide gel copolymerized with $0.1 \%$ gelatin for substrate reaction). After washing in $2.5 \%$ Triton X-100 to remove SDS, gels were then incubated with developing buffer $(50 \mathrm{mM}$ Tris- $\mathrm{HCl} \mathrm{pH}$ 7.4, $200 \mathrm{mM}$ $\mathrm{NaCl}, 5 \mathrm{mM} \mathrm{CaCl}_{2}$ and $0.02 \%$ Briji-35) at $37^{\circ} \mathrm{C}$ for $>12 \mathrm{~h}$. Gels were then stained with $0.5 \%$ Coomassie Brilliant Blue R-250 for $2 \mathrm{~min}$ for band observation. The intensities of bands were quantified with ImageJ software (National Institutes of Health, Bethesda, MA, USA). The sum of MMP-9 and MMP-2 bands was determined as activity.

Western blot analysis. The western blot analysis was performed as described previously (26). Proteins were extracted using lysis buffer $(1 \mathrm{M}$ Tris- $\mathrm{HCl}, \mathrm{pH} 7.4 ; 1 \mathrm{M} \mathrm{NaCl}$; $20 \%$ Triton X100; $10 \%$ SDS; and 0.5 M EDTA). Protein concentration was determined by bicinchoninic acid method as described previously (27). A total of $20 \mu \mathrm{g}$ protein was loaded per lane of a $12 \%$ polyacrylamide gel. The polyvinylidene fluoride membrane (Thermo Fisher Scientific, Inc., Waltham, MA, USA) was treated with Block Ace ${ }^{\mathrm{TM}}(4 \%)$ for $30 \mathrm{~min}$ at $22^{\circ} \mathrm{C}$. The first reaction was performed using rabbit immunoglobulin (Ig)G antibodies against JNK (cat. no. J4500; 1:2,000), phospho-JNK (cat. no. 07-175; $2 \mu \mathrm{g} / \mathrm{ml}$ ), p53 (cat. no. SAB4503015; 1:500), caspase-9 (cat. no. C7729; 1:300), caspase-3 (cat. no. C9598; 1:3,000) and p38 MAPK (cat. no. SAB4500492; 1:500) (all from Sigma-Aldrich; Merck KGaA) in PBS containing $0.03 \%$ Tween-20 for $1 \mathrm{~h}$ at room temperature. Following washing in the same buffer three times, the second reaction was performed using horseradish peroxidase-conjugated anti-rabbit goat IgG (cat. no. A0545; $20 \mathrm{ng} / \mathrm{ml}$; Sigma-Aldrich; Merck KGaA) for $30 \mathrm{~min}$ at room temperature. Following washing, enhanced chemiluminescence (ECL) was used to incubate the membrane and visualized using the ECL Plus Western Blotting Detection System $^{\mathrm{TM}}$ (GE Healthcare Life Sciences, Little Chalfont, UK). Image J (version 1.49v; National Institutes of Health, Bethesda, MD, USA) was used for the densitometry analysis of western blots.

Detection of intracellular reactive oxygen species (ROS). Intracellular accumulation of ROS was estimated using the fluorescent dye H2-dichlorofluorescin diacetate (DCFDA; Life Technologies; Thermo Fisher Scientific, Inc.), which is converted to a membrane impermeable and highly fluorescent compound, dichlorofluorescin (DCF), in the presence 
A

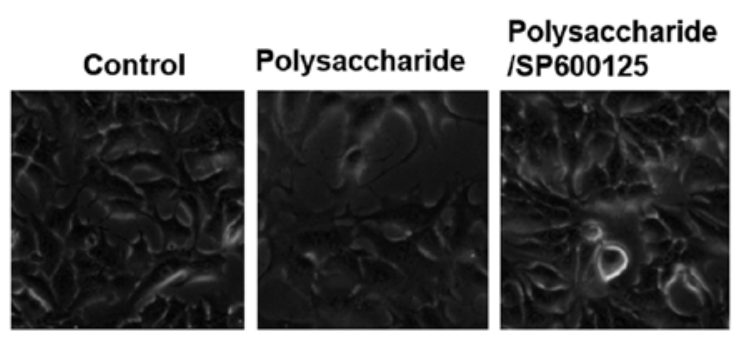

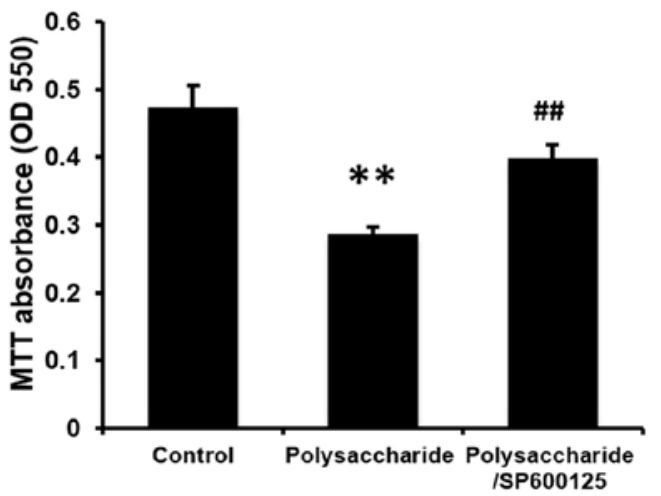

B

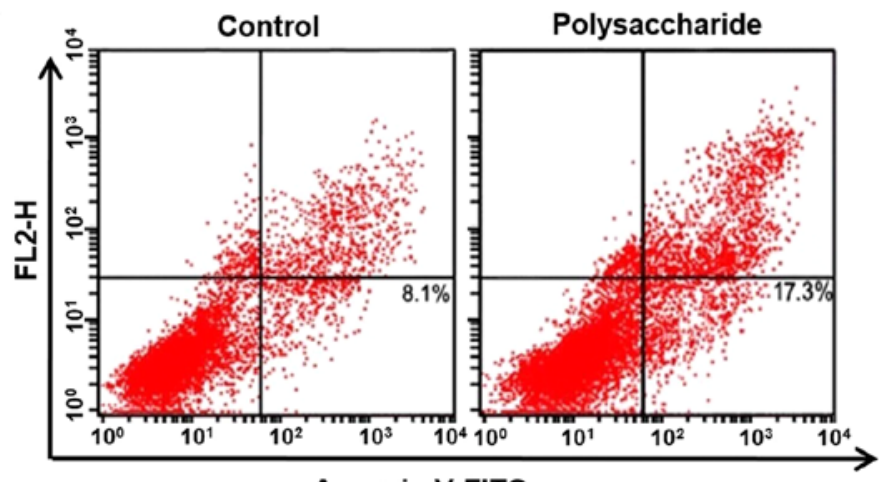

Annexin V-FITC

\section{C}

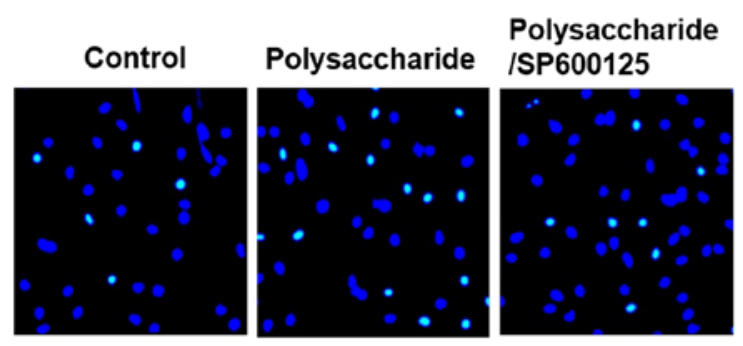

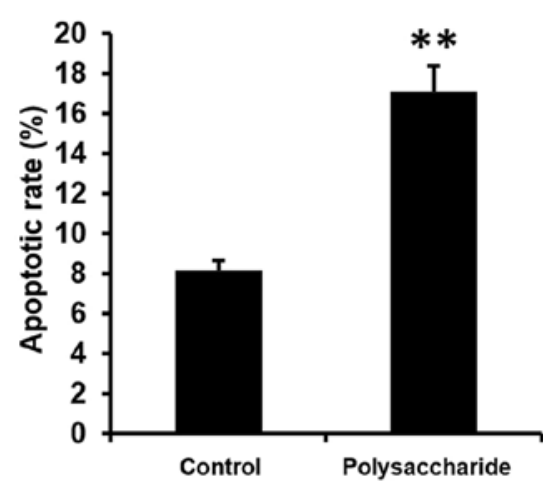

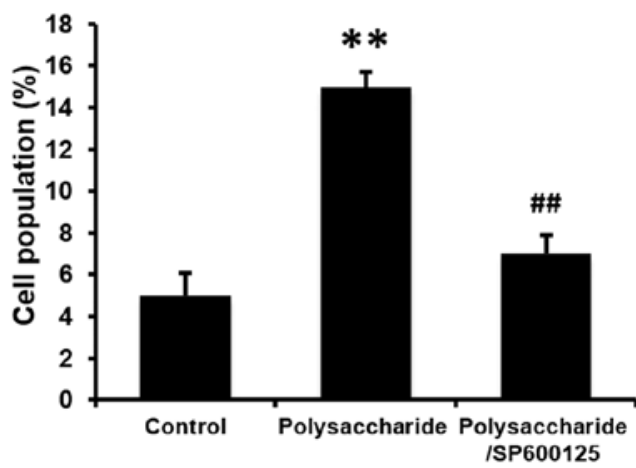

Figure 2. The novel polysaccharide reduces cell viability, and induces cell apoptosis in MCF-7 cells, and SP600125 inhibits the effects. Human MCF-7 breast cancer cells were treated with $100 \mu \mathrm{g} / \mathrm{ml}$ polysaccharide for $48 \mathrm{~h}$ and a group were pretreated with $5 \mu \mathrm{M} \mathrm{SP600125} \mathrm{(inhibitor} \mathrm{of} \mathrm{Jun} \mathrm{N-terminal} \mathrm{kinase).}$ (A) MMT assay was used to determine cell viability. (B) Cell apoptosis was determined by flow cytometry. (C) Nuclear staining was performed to indicate apoptotic cells. Data are expressed as the mean \pm standard deviation $(n=3) .{ }^{* *} \mathrm{P}<0.01$ vs. control. FITC, fluorescein isothiocyanate.

of ROS. The MCF-7 cells were seeded in a 6-well plate at the density of $1 \times 10^{5}$ cells/well. Following treatment with the polysaccharide $(100 \mu \mathrm{g} / \mathrm{ml})$ or SP600125 $(5 \mu \mathrm{M}), \mathrm{MCF}-7$ cells ( $1 \times 10^{5}$ cells/well) were further incubated for $48 \mathrm{~h}$. The cells were rinsed with serum-free medium and were incubated in $5 \mu \mathrm{M} \mathrm{H} 2-\mathrm{DCFDA}$ for $60 \mathrm{~min}$ at $37^{\circ} \mathrm{C}$. The cells were then examined under a fluorescence microscope (C1-T-SM; Nikon Corporation, Tokyo, Japan), collected and subjected to a fluorescence spectrophotometry (F-2500; Hitachi, Ltd., Tokyo, Japan) to detect the DCF fluorescence inside cells (excitation, $488 \mathrm{~nm}$; emission, $521 \mathrm{~nm}$ ) as described (8).

Statistical analysis. Analyses were performed using SPSS 19.0 (IBM Corp., Armonk, NY, USA). All data were presented as the mean \pm standard deviation of three independent experiments. Normality of distribution was analyzed by D'Agostino and Pearson omnibus normality test. Multiple comparisons between groups were performed using one-way analysis of variance and post hoc test (Dunnett's test). $\mathrm{P}<0.05$ was considered to indicate a statistically significant difference.

\section{Results}

Novel polysaccharide suppresses cell proliferation, induces cell apoptosis and cell cycle arrest in MCF-7 cells. Recently, we reported that the polysaccharide inhibited the invasion ability of human MKN45 gastric carcinoma cells (8). To better understand whether the polysaccharide has similar efficacy on other types of cancer cells, the viability of human MCF-7 breast cancer cells was determined. MCF-7 cells were exposed to $100 \mu \mathrm{g} / \mathrm{ml}$ polysaccharide for $48 \mathrm{~h}$ and the cellular viability measured by colorimetric MTT assay. The viability of MCF-7 cells was reduced by the polysaccharide treatment (Fig. 2A). As the inhibition of viability is typically caused by increased 
A

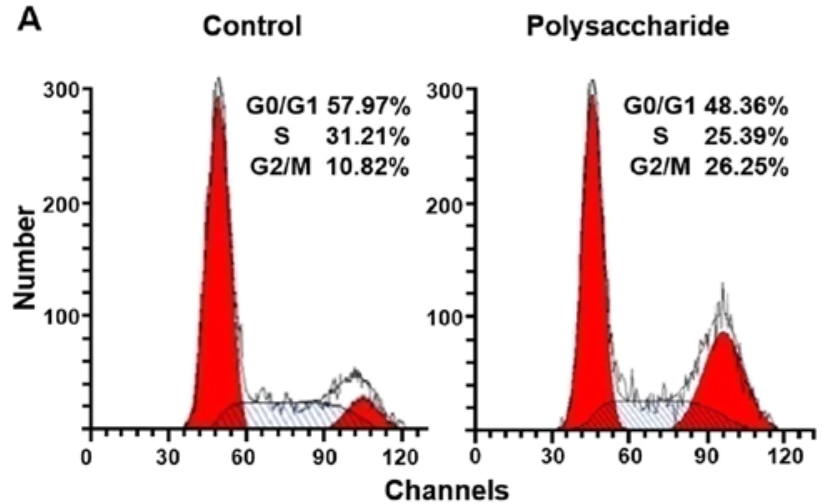

B
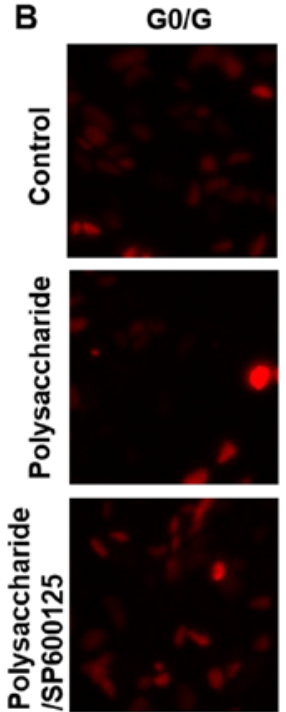

G2/M
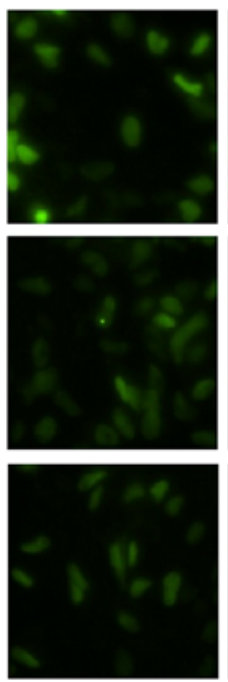

\section{Overlay}
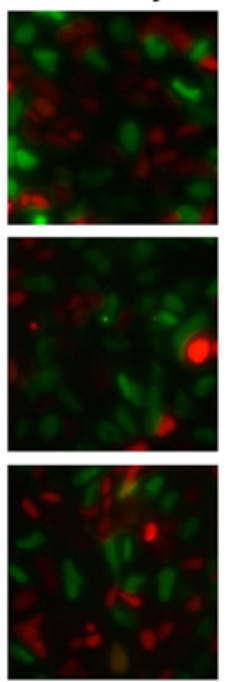
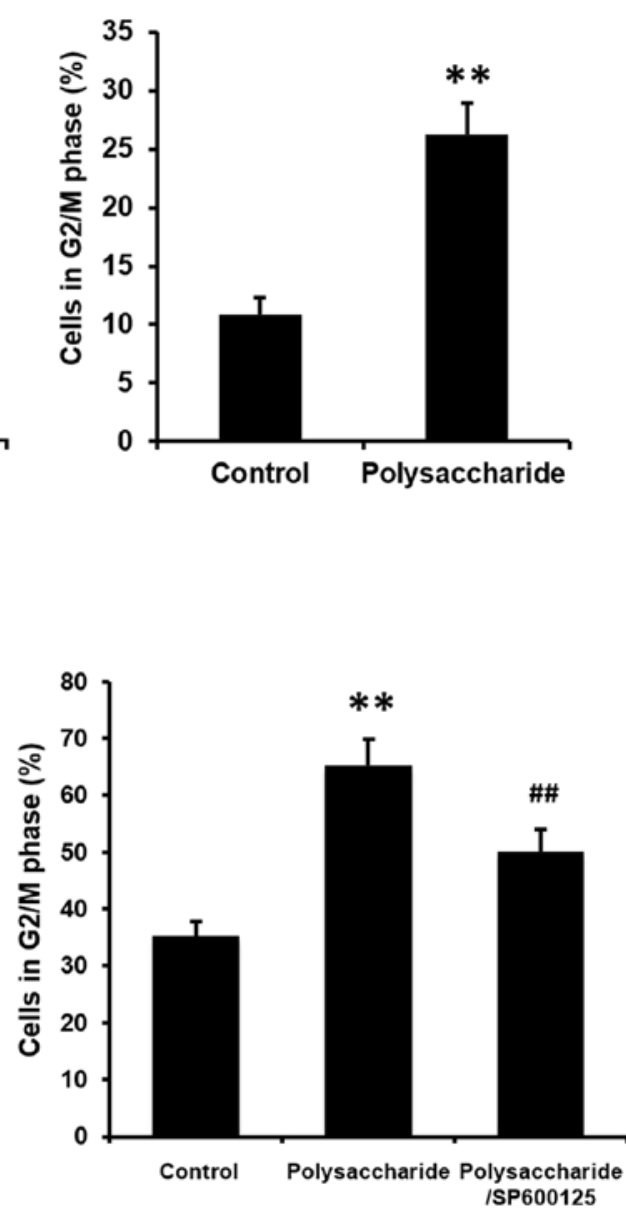

Figure 3. The novel polysaccharide blocks the cell cycle, and SP600125 inhibits the effects on the cell cycle arrest in MCF-7 cells. MCF-7 cells were pretreated with $5 \mu \mathrm{M}$ SP600125 (inhibitor for Jun N-terminal kinase) for $1 \mathrm{~h}$, and then treated with polysaccharide (100 $\mu \mathrm{g} / \mathrm{ml}$ ) for $48 \mathrm{~h}$. Cell cycle was analyzed by (A) flow cytometry and (B) Fucci system. Magnification, $\mathrm{x} 400$. Data are expressed as the mean \pm standard deviation ( $\mathrm{n}=3$ ). ${ }^{* *} \mathrm{P}<0.01$ vs. control; ${ }^{\# \#} \mathrm{P}<0.01$ vs. polysaccharide group.

cellular apoptosis, FACSCalibur ${ }^{\mathrm{TM}}$ flow cytometry and nuclear staining were performed to determine cell apoptosis. The polysaccharide induced cell apoptosis compared with the cells without polysaccharide treatment (Fig. 2B and C). Considering that the suppressed cell growth may be due to the cell cycle arrest, flow cytometry and a Fucci system were used to analyze the cell cycle. The polysaccharide arrested the cell cycle at G2/M (Fig. 3). These results indicate that the novel polysaccharide reduced MCF-7 cells viability, and induces apoptosis and cell cycle arrest, which are consistent with the results in our previous study (8).

Lack of inhibitory effects of the novel polysaccharide on migration or MMP-9/MMP-2 expression in MCF-7 cells. Migratory capacity is another characteristic of cancer cells. In order to understand whether the polysaccharide affects MCF-7 cells by inhibiting cell migration, we used a migration assay kit to determine the cell migration. There was no difference in the number migrated cells between the polysaccharidetreated and non-treated MCF-7 cells (Fig. 4A). Furthermore, the MMP-9/MMP-2 mRNA expression was measured, which was reported to be important for the migration of cancer cells. MMP-9/MMP2 mRNA expression (Fig. 4B and C) and the
MMP activity (Fig. 4D) were not changed in polysaccharidetreated MCF-7 cells compared with control cells. These results suggested that the polysaccharide does not affect the migration of MCF-7 cells.

Novel polysaccharide induces the phosphorylation of JNK, and expression of p53, caspase-9 and caspase-3, with no effect on 38 MAPK phosphorylation in MCF-7 cells. The results of the current study demonstrated that the polysaccharide inhibited MCF-7 cell viability, induced cell apoptosis and cell cycle arrest, without affecting the migration of MCF-7 cells. To further determine the potential signaling pathways involved in this process, western blot analysis was performed to detect the phosphorylation of JNK and p38 MAPK, and expression of p53, caspase-9 and caspase-3. The novel polysaccharide upregulated the phosphorylation of JNK, and the expression of p53, caspase-9 and caspase-3 $(\mathrm{P}<0.01)$, however, there was no effect on p38 MAPK phosphorylation in MCF-7 cells (Fig. 5A and B). These results indicate that, the novel polysaccharide inhibits MCF-7 cell viability, and induces cell apoptosis and cell cycle arrest via JNK signaling, whereas there was no effect on cancer cell or p38 MAPK phosphorylation. 
A
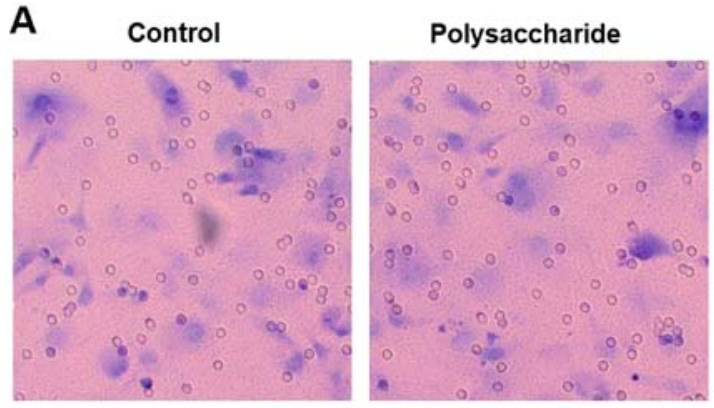

B
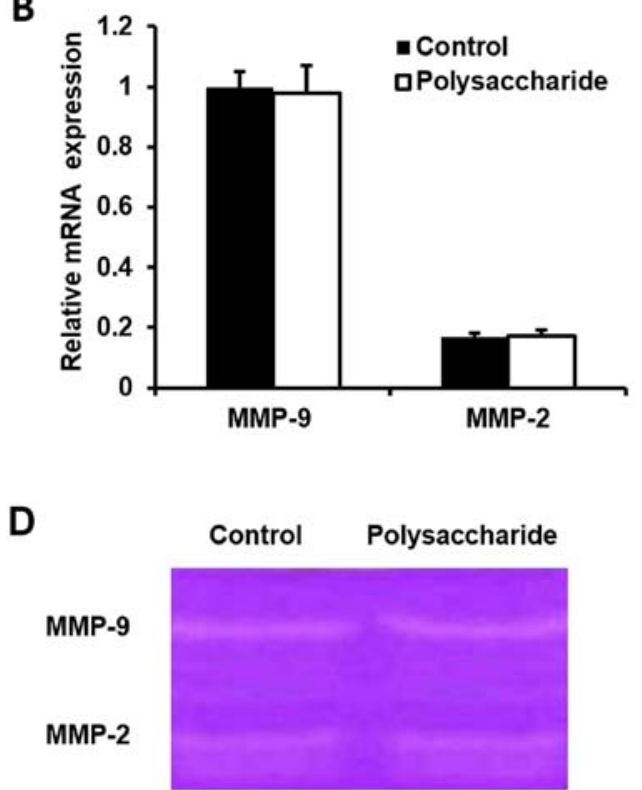

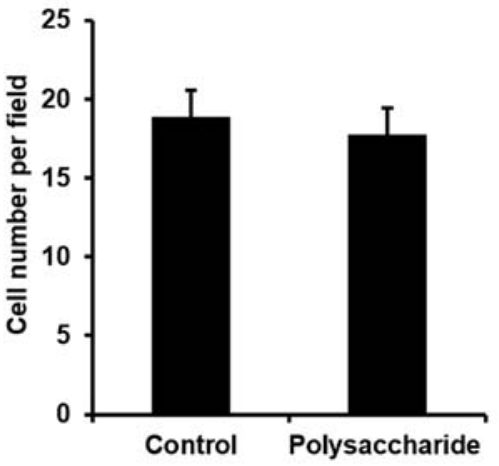

C
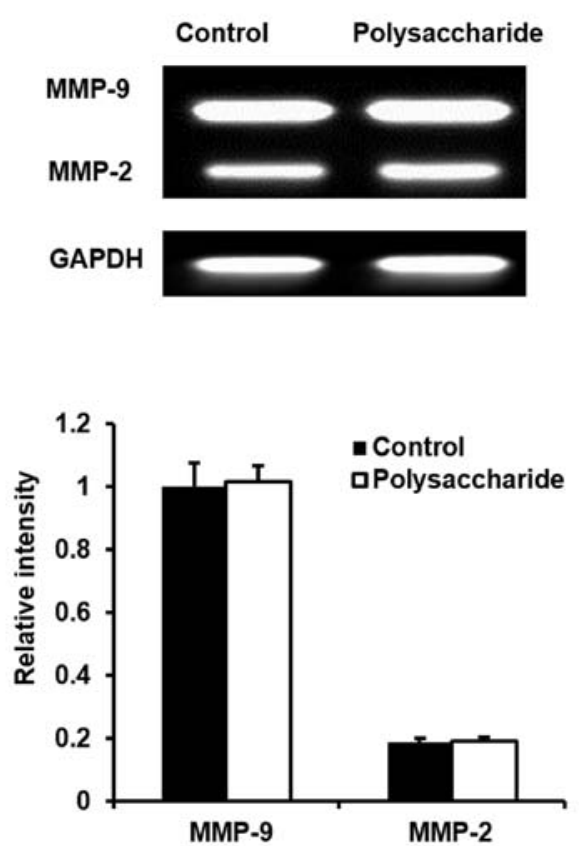

Figure 4. The novel polysaccharide does not alter migration or MMP-9/MMP-2 mRNA expression in MCF-7 cells. MCF-7 cells were treated with $100 \mu \mathrm{g} / \mathrm{ml}$ polysaccharide for $48 \mathrm{~h}$. (A) Cell migration was determined using a migration assay kit, cells were stained with crystal violet. The novel polysaccharide didn't affect the migration of MCF-7 cells. Magnification, x400. MMP-9/MMP-2 mRNA expression was analysis by (B) reverse transcription-quantitative polymerase chain reaction and (C) PCR products were observed on an agarose gel. (D) MMP-9/MMP-2 activity was determined by gelatin zymography. There was no change in MMP-9/MMP-2 mRNA expression or MMP-9/MMP-2 activity in the polysaccharide-treated MCF-7 cells. Data are expressed as the mean \pm standard deviation $(\mathrm{n}=3)$. MMP, matrix metalloproteinase.

SP600125 inhibits the effects of the novel polysaccharide on cell viability, apoptosis and cell cycle arrest in MCF-7 cells. In order to establish whether JNK signaling pathway is necessary for this process, MCF-7 cells were pretreated with SP600125, an inhibitor of JNK $(5 \mu \mathrm{M})$ for $1 \mathrm{~h}$. Notably, SP600125 significantly blocked the polysaccharide-induced reduction in cell viability (Fig. 2A) and prevented polysaccharide induced cell apoptosis (Fig. 2C) and cell cycle arrest (Fig. 3B; P<0.01).

SP600125 prevents the novel polysaccharide-induced p53, caspase-9 and caspase-3 in MCF-7 cells. To further clarify whether JNK signaling is necessary in the potential processes induced by the polysaccharide, cells were treated with SP600125 prior to western blot analysis of various proteins. SP600125 significantly prevented the polysaccharide-induced expression of p53, caspase-9 and caspase-3 in MCF-7 cells (Fig. 5A and $\mathrm{C} ; \mathrm{P}<0.05$ ). These results were consistent with our previous finding (8) and indicated that JNK signaling is crucial and necessary in this process.
SP600125 does not affect the novel polysaccharide-induced ROS generation in MCF-7 cells. Previously, MKN45 cells were used to investigate the mechanisms of JNK/ROS (8). As the activation of JNK is associated with ROS generation, ROS generation was analyzed in MCF-7 cells in the current study. MCF-7 cells were pretreated with $5 \mu \mathrm{M}$ SP600125 (a JNK inhibitor) for $1 \mathrm{~h}$ prior to the polysaccharide $(100 \mu \mathrm{g} / \mathrm{ml})$ treatment. Subsequently, the cells were incubated further for $48 \mathrm{~h}$. Intracellular accumulation of ROS was estimated using the fluorescent dye H2-DCFDA and flow cytometry. The novel polysaccharide significantly induced ROS generation in MCF-7 cells (Fig. 5D; $\mathrm{P}<0.01$ ). However, pretreatment with SP600125 did not affect the polysaccharide-induced ROS generation in MCF-7 cells, suggesting that the effects on ROS are upstream of JNK.

SP600125 prevents the novel polysaccharide-induced cell proliferation and apoptosis in human cervical cancer cell line (HeLa cells). The biological activity of the novel polysaccharide 
A
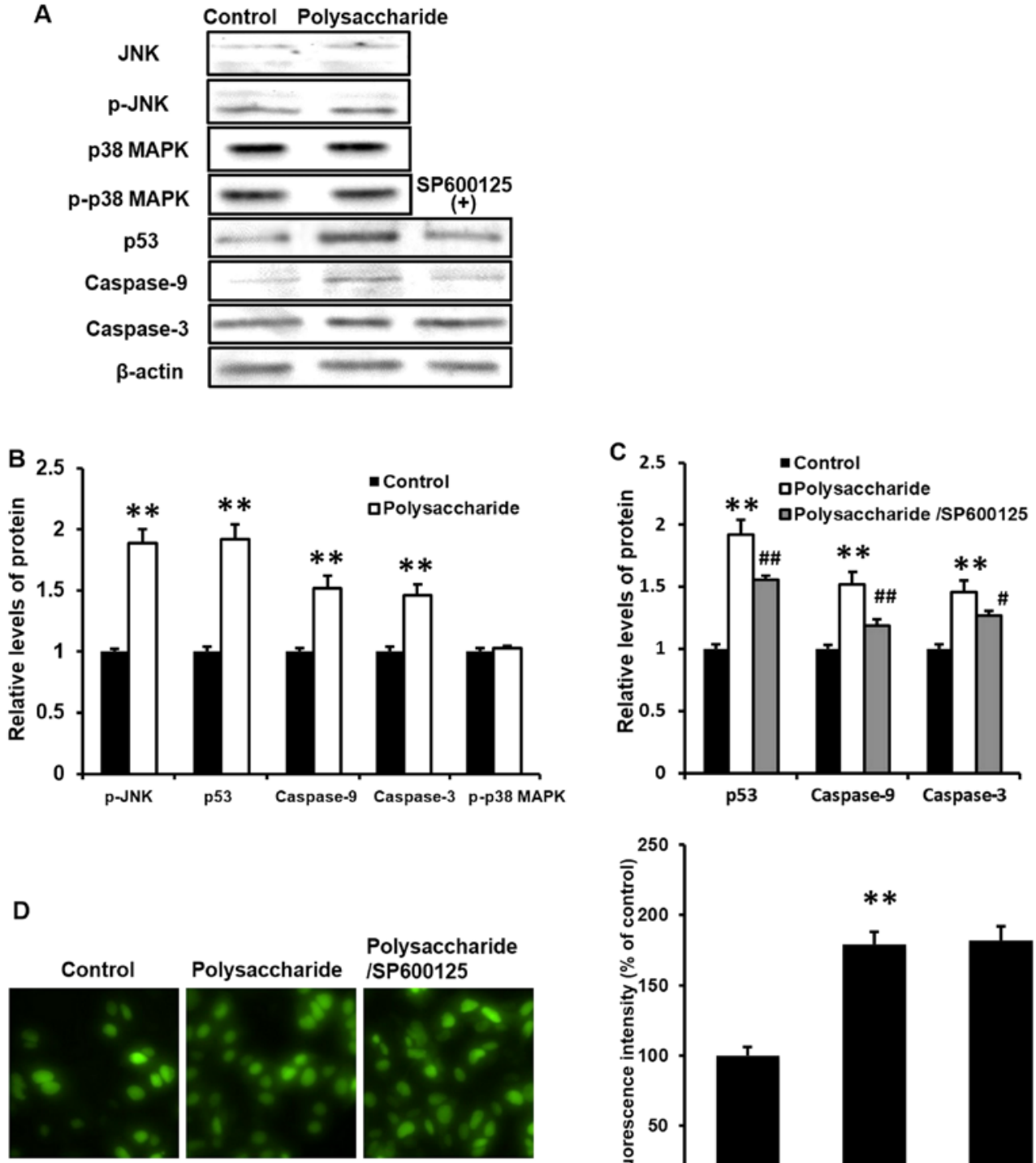

Polysaccharide
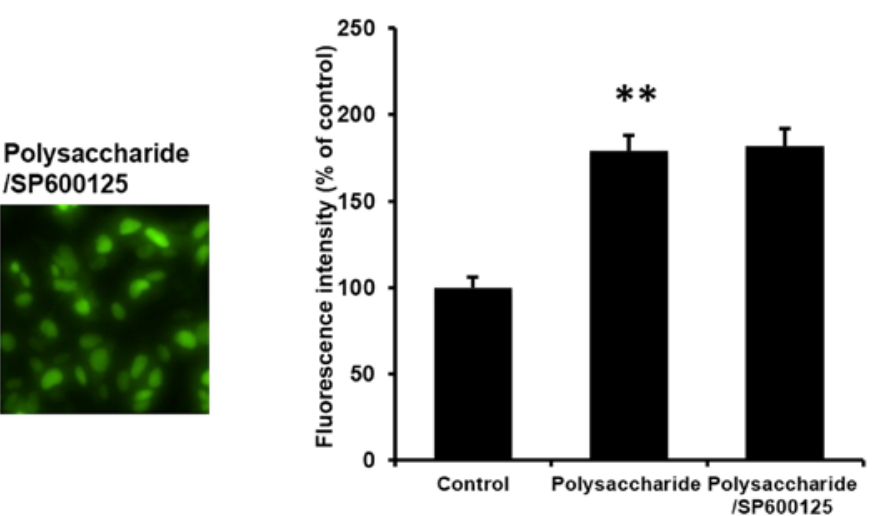

Figure 5. Effect of the novel polysaccharide on cell signaling pathways. MCF-7 cells were pretreated with $5 \mu \mathrm{M} \mathrm{SP600125}$ (inhibitor of JNK) for $1 \mathrm{~h}$, and then treated with polysaccharide (100 $\mu \mathrm{g} / \mathrm{ml})$ for $48 \mathrm{~h}$. (A) p-JNK, p53, caspase-9, caspase-3 and p38 MAPK were determined by western blot analysis. (B) Effect of polysaccharide on protein expression by densitometry. (C) Effect of polysaccharide and SP600125 on protein expression by densitometry. Magnification, x400. (D) Effect of polysaccharide and SP600125 on ROS generation in MCF-7 cells using H2-dichlorofluorescin diacetate. Data are expressed as the mean \pm standard deviation $(\mathrm{n}=3)$. ${ }^{* *} \mathrm{P}<0.01$ vs. control; ${ }^{~} \mathrm{P}<0.05$ and ${ }^{\# \#} \mathrm{P}<0.01$ vs. polysaccharide group. $\mathrm{p}-$, phospho-; JNK, Jun N-terminal kinase; MAPK, mitogen-activated protein kinase.

in HeLa cells was also investigated. The novel polysaccharide inhibited cell viability and induced cell apoptosis in HeLa cells. SP600125 significantly prevented the cell viability inhibition and cell apoptosis induction by the polysaccharide. (Fig. 6; $\mathrm{P}<0.01)$.

\section{Discussion}

Cancer is a major cause of mortality globally (28). Surgery and radiotherapy are the most common therapies (2); however, due to the accompanied side-effects $(1,29)$, it is necessary and crucial to develop novel treatment strategies for cancer with reduced side-effects. In recent years, research has focused on molecular-targeted treatment for cancers (30) and the interest in biological activities of compounds from marine organisms has intensified (6). Numerous compounds have been investigated, and some have been developed into herbal medicine in Japan and elsewhere (6). A novel polysaccharide derived from algae extract was investigated in this study. The biological activity of this compound on human MKN45 gastric carcinoma cells via activating ROS/JNK signaling pathway was reported previously (8), and in the current study, another type of human cancer cell was used, human MCF-7 breast cancer cells, to investigate the polysaccharide for anticancer activity and the mechanisms involved. As described in our previous study (8), the effect of this novel polysaccharide in inhibiting human gastric carcinoma MKN45 cells was measured in preexperiments, where the effects were dose-dependent $(1,10$, 100 and $1,000 \mu \mathrm{g} / \mathrm{ml}$ ) and time-dependent $(12,24$ and $48 \mathrm{~h})$. A significant difference was reached at $100 \mu \mathrm{g} / \mathrm{ml}$ and at $48 \mathrm{~h}$. 
A

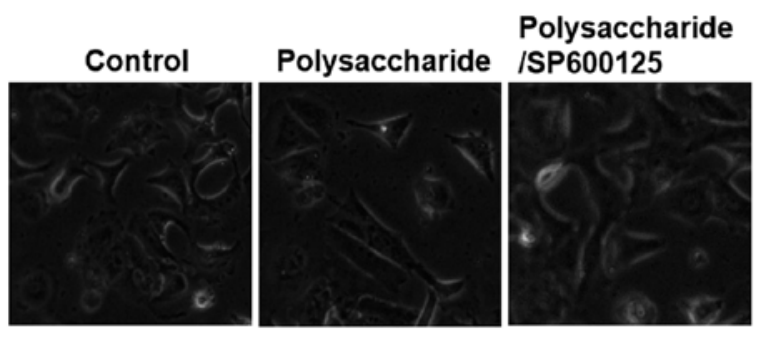

B

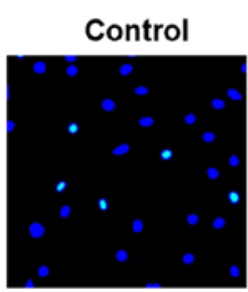

Polysaccharide

Polysaccharide

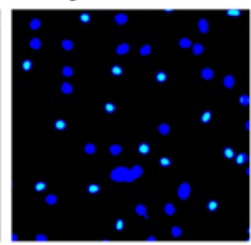

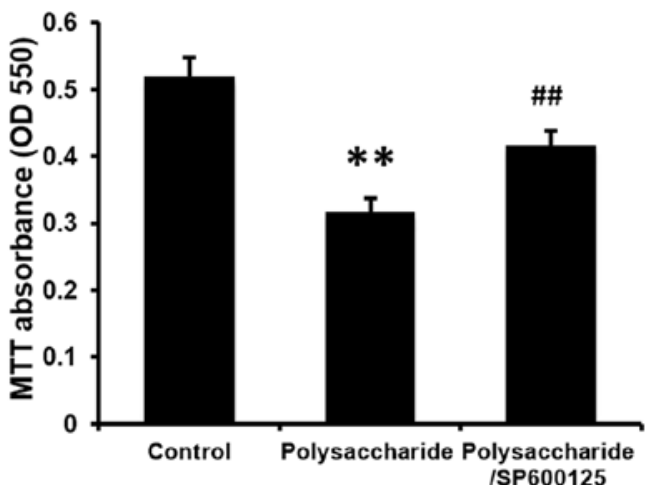

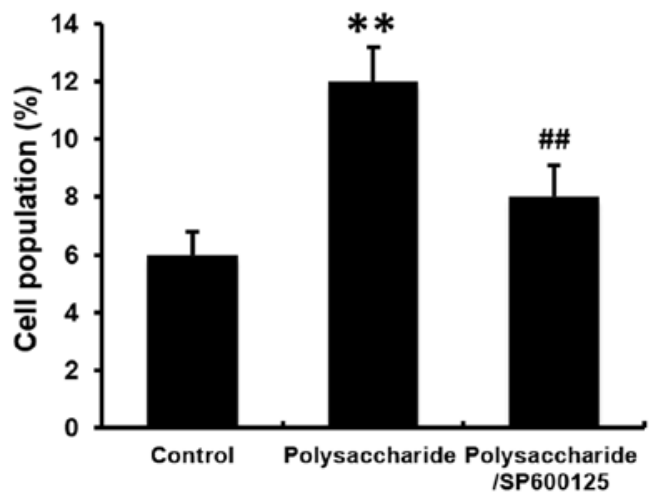

Figure 6. SP600125 inhibits the effects of the novel polysaccharide on cell proliferation, cell apoptosis and cell cycle arrest in HeLa cells. HeLa cells were pretreated with SP600125 (inhibitor of Jun N-terminal kinase; $5 \mu \mathrm{M}$ ) for $1 \mathrm{~h}$, and then treated with polysaccharide (100 $\mu \mathrm{g} / \mathrm{ml}$ ). (A) Cell viability and (B) cell apoptosis were determined by MTT assay and nuclear staining, respectively. Magnification, $\mathrm{x} 400$. Data are expressed as the mean \pm standard deviation ( $\mathrm{n}=3$ ). ${ }^{* *} \mathrm{P}<0.01$ vs. control; ${ }^{\# \#} \mathrm{P}<0.01$ vs. polysaccharide group.

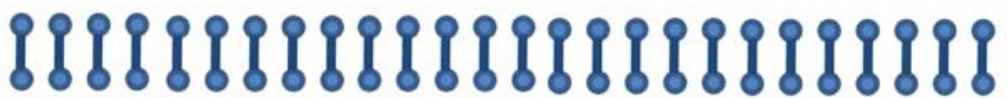

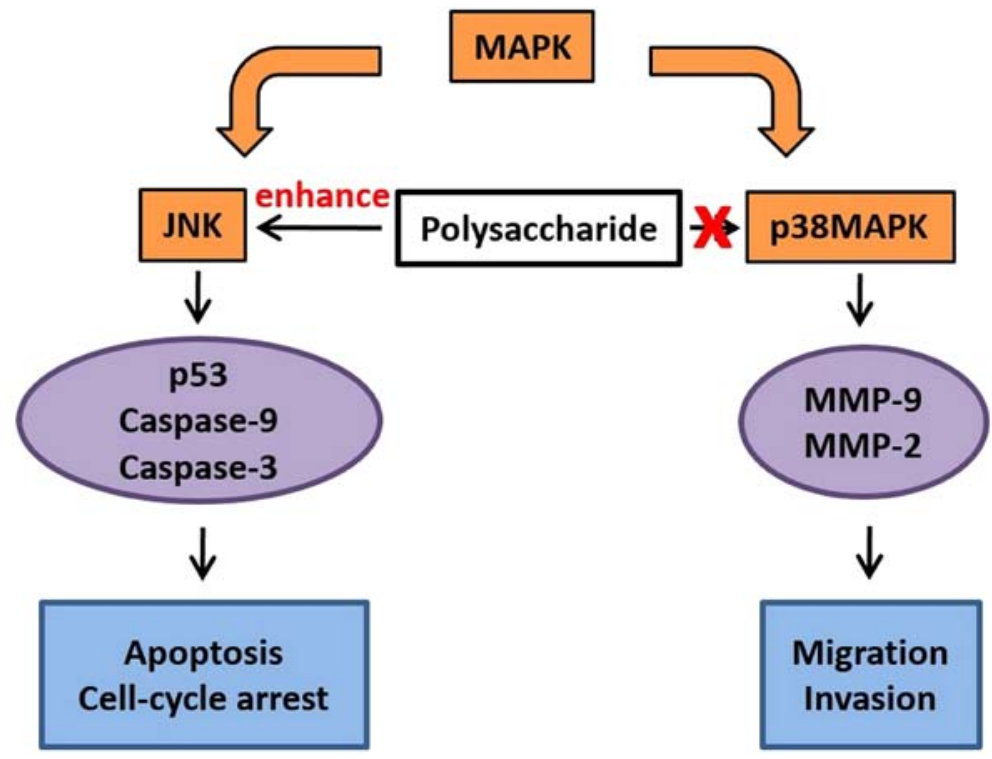

Figure 7. Proposed mechanism of the inhibitory process. The novel polysaccharide derived from algae extract upregulates the phosphorylation of JNK, activates the downstream cascades of p53, caspase- 9 and caspase-3, and then leads to the inhibition of cancer cell proliferation, induces cell apoptosis and cell cycle arrest. By contrast, the polysaccharide does not affect the cancer cell migration, which is mediated through the p38 MAPK signaling pathway or the downstream MMP-9/MMP-2. JNK, Jun N-terminal kinase; MAPK, mitogen-activated protein kinase; MMP, matrix metalloproteinase.

Thus, $100 \mu \mathrm{g} / \mathrm{ml}$ of polysaccharide and $48 \mathrm{~h}$ of treatment was used in the current study.
Abnormal proliferation and migration have important physiological roles in the process of cancer invasion (8). 
Apoptosis and programmed cell death are crucial mechanisms of proliferation inhibition (10). The majority of chemotherapeutic agents inhibit cancer development by inducing the mechanisms of apoptosis and programmed cell death (31). In accordance with the conclusions of previous experiments using MKN45 cells (8), the present study demonstrated that the novel polysaccharide reduced cell viability and induced apoptosis in MCF-7 cells. In addition to apoptosis, cell cycle arrest is another cause of proliferation inhibition (11). Various anticancer drugs inhibit cell cycle progression at the G0/G1, $\mathrm{S}$ or $\mathrm{G} 2 / \mathrm{M}$ phases (32). Abnormal cell cycle regulation has been linked with cancer progression, and cell cycle arrest is an effective method to block cancer cell proliferation $(33,34)$. Various anticancer drugs synchronize tumor cells in $\mathrm{M}$ phase, which is the most radiosensitive stage of the cell cycle (35), appropriate timing of administration results in optimal radiosensitization (36). With the use of the Fucci system in the present study confirmed that the novel polysaccharide arrested MCF-7 cells at G2/M phase. These results again demonstrated the potential ability of the novel polysaccharide in blocking the development of cancers.

The development to cancer is often associated with JNK, p38 MAPK and other signaling pathways. The MAPK family includes extracellular signal-regulated kinase (ERK), p38, JNK and ERK5 (37). MAPK signaling pathways are the most widespread mechanisms of eukaryotic cell regulation (38), including cell cycle, proliferation and migration regulation (12). JNK, an important member of MAPK family, is reported to be associated with cell proliferation inhibition (13). The activated phospho-JNK induces the expression of downstream tumor suppressors (14). p53, a tumor suppressor, is involved in coordinating apoptosis to preserve genomic stability and prevent tumor formation. Previous studies have also suggested the involvement of p53 in the autophagic pathway (39). p53 induces cell cycle arrest and leads to selfmediated apoptosis (40). In addition, p53 also induces the expression of several factors involved in apoptosis, including caspase- 9 and caspase- 3 (41). The activation of caspase- 9 and caspase- 3 induces proteolysis and leads to the damage of cell structure and functional disorder (42). Phosphorylated JNK activates p53, caspase- 9 and caspase- 3 , consequently leading to apoptosis and cell cycle arrest (14). The current study demonstrated that the novel polysaccharide induced the phosphorylation of JNK, and increased the expression of $\mathrm{p} 53$, caspase- 9 and caspase-3, suggesting the involvement of JNK activation, and p53, caspase- 9 and caspase -3 expression in the inhibitory effects of the novel polysaccharide.

p38 MAPK is another member of the MAPK family. p38 MAPK signaling is the main pathway involved in inducing cell migration (43). Notably, in the current study, the novel polysaccharide did not affect the migration of MCF-7 cells. MMP-9 and MMP-2 are key enzymes involved in tumor metastasis (44). p38 MAPK signaling increases the activity of MMP-9 and MMP-2 and induces cell migration (15). To better understand whether the p38 MAPK signaling pathway is involved in the effects of the polysaccharide, the expression of p38 MAPK, MMP-9 and MMP-2 were examined in the present study. The polysaccharide did not affect the mRNA expression or activity of MMP-9 and MMP-2, or the phosphorylation of $\mathrm{p} 38$ MAPK. These results suggested that the p38 MAPK signaling pathway and its downstream cascades were not involved in the inhibitory effects of the algae polysaccharide.

To understand the role of JNK in the effects of the novel polysaccharide, the JNK inhibitor SP600125 was used in further experiments. SP600125 significantly blocked the reduced MCF-7 cell viability cause by the novel polysaccharide, prevented the induction of cell apoptosis and cell cycle arrest. Additionally, SP600125 prevented the novel polysaccharide-induced expression of p53, caspase- 9 and caspase-3 in MCF-7 cells. The association between activation JNK and ROS generation was reported in our previous study (8); thus, in the current study, the, generation of ROS was determined in MCF-7 cells. The novel polysaccharide significantly induced ROS generation in MCF-7 cells; however, pretreatment with SP600125 did not affect the polysaccharide-induced ROS generation in MCF-7 cells, suggesting that the effect on ROS is upstream of JNK.

Currently, three types of cancer cells have been used to investigate the biological activities of the novel polysaccharide. MKN45 cells were used in our previous study (8) and MCF-7 cells were used in the current study. In order to support the findings, experiments were also performed in HeLa cells, with the novel polysaccharide exerting similar effects on cell viability and cell apoptosis. SP600125 significantly inhibited the reduced cell viability and increased cell apoptosis induced by the polysaccharide.

A proposed pathway summary is presented in Fig. 7. The novel polysaccharide derived from algae extract upregulates the phosphorylation of JNK, activates the downstream cascades of p53, caspase- 9 and caspase-3, and the leads to the inhibition of cancer cell growth, and induces cell apoptosis and cell cycle arrest. By contrast, the polysaccharide did not alter cancer cell migration, which is typically mediated through p38 MAPK signaling pathway or MMP-9/MMP-2 downstream.

The findings of the current study demonstrated that the novel polysaccharide suppressed cancer cell proliferation, induced cancer cell apoptosis and arrested the cell cycle via JNK signaling, whereas cancer cell migration was not inhibited and there was no effect on p38 MAPK signaling pathway. The application of the polysaccharide derived from algae extract may provide a key insight into the development of novel clinical treatment for cancers with reduced side-effects. However, in addition to JNK and p38 MAPK, many signaling pathways are involved in the processes of cancer development; the deeper and more complicated mechanisms will be examined in further investigations.

\section{Acknowledgements}

Not applicable.

\section{Funding}

No funding was received.

\section{Availability of data and materials}

The datasets used and/or analyzed during the current study are available from the corresponding author on reasonable request. 


\section{Authors' contributions}

PX was a major contributor in performing experiments and writing the manuscript. FH was an assistant for experiments. IF provided technical assistance. JZ and MS provided the novel polysaccharide and technical assistance. MM was the leader of this study. All authors read and approved the final manuscript.

\section{Ethics approval and consent to participate}

Not applicable.

\section{Consent for publication}

Not applicable.

\section{Competing interests}

The authors declare that they have no competing interests.

\section{References}

1. Chen L, Jiang Z, Ma H, Ning L, Chen H, Li L and Qi H: Volatile oil of Acori Graminei Rhizoma-induced apoptosis and autophagy are dependent on p53 status in human glioma cells. Sci Rep 6: 21148,2016

2. Wu S, Powers S, Zhu W and Hannun YA: Substantial contribution of extrinsic risk factors to cancer development. Nature 529: 43-47, 2016.

3. Brody JG, Rudel RA, Michels KB, Moysich KB, Bernstein L, Attfield KR and Gray S: Environmental pollutants, diet, physical activity, body size, and breast cancer: Where do we stand in research to identify opportunities for prevention? Cancer 109 (Suppl 12): 2627-2634, 2007.

4. Wang H, Wei L, Li C, Zhou J and Li Z: CDK5RAP1 deficiency induces cell cycle arrest and apoptosis in human breast cancer cell line by the ROS/JNK signaling pathway. Oncol Rep 33: 1089-1096, 2015.

5. Onofrejová L, Vasícková J, Klejdus B, Stratil P, Misurcová L, Krácmar S, Kopecký J and Vacek J: Bioactive phenols in algae: The application of pressurized-liquid and solid-phase extraction techniques. J Pharm Biomed Anal 51: 464-470, 2010.

6. Abdjul DB, Yamazaki H, Kanno S, Takahashi O, Kirikoshi R, Ukai K and Namikoshi M: Structures and biological evaluations of agelasines isolated from the Okinawan marine sponge Agelas nakamurai. J Nat Prod 78: 1428-1433, 2015.

7. Xie P, Fujii I, Zhao J, Shinohara M and Matsukura M: A novel polysaccharide compound derived from algae extracts protects retinal pigment epithelial cells from high glucose-induced oxidative damage in vitro. Biol Pharm Bull 35: 1447-1453, 2012.

8. Xie P, Fujii I, Zhao J, Shinohara M and Matsukura M: A novel polysaccharide derived from algae extract induces apoptosis and cell cycle arrest in human gastric carcinoma MKN45 cells via ROS/JNK signaling pathway. Int J Oncol 49: 1561-1568, 2016.

9. Peng R, Li Z, Lin Z, Wang Y, Wang W, Hu B, Wang X, Zhang J, Wang Y, Zhou R, et al: The HSP90 inhibitor 17-PAG effectively inhibits the proliferation and migration of androgen-independent prostate cancer cells. Am J Cancer Res 5: 3198-3209, 2015.

10. Pal D, Sharma U, Singh SK, Kakkar N and Prasad R: Overexpression of telomere binding factors (TRF1 \& TRF2) in renal cell carcinoma and their inhibition by using siRNA induce apoptosis, reduce cell proliferation and migration in vitro. PLoS One 10: e0115651, 2015.

11. Tian X, Yang N, Li B, Zhang J, Xu X, Yue R, Li H, Chen L, Shen Y and Zhang W: Inhibition of HL-60 cell growth via cell cycle arrest and apoptosis induction by a cycloartane-labdane heterodimer from Pseudolarix amabilis. Org Biomol Chem 14 2618-2624, 2016.

12. Deng L, Yang J, Chen H, Ma B, Pan K, Su C, Xu F and Zhang J: Knockdown of TMEM16A suppressed MAPK and inhibited cell proliferation and migration in hepatocellular carcinoma. Onco Targets Ther 9: 325-333, 2016.
13. Uchakina ON, Ban $\mathrm{H}$ and McKallip RJ: Targeting hyaluronic acid production for the treatment of leukemia: Treatment with 4-methylumbelliferone leads to induction of MAPK-mediated apoptosis in K562 leukemia. Leuk Res 37: 1294-1301, 2013.

14. Leber B, Geng F, Kale J and Andrews DW: Drugs targeting Bcl-2 family members as an emerging strategy in cancer. Expert Rev Mol Med 12: e28, 2010.

15. Yang L, Shu T, Liang Y, Gu W, Wang C, Song X, Fan C and Wang W: GDC-0152 attenuates the malignant progression of osteosarcoma promoted by ANGPTL2 via PI3K/AKT but not p38 MAPK signaling pathway. Int J Oncol 46: 1651-1658, 2015.

16. Zhang Z, Yu G, Guan H, Zhao X, Du Y and Jiang X: Preparation and structure elucidation of alginate oligosaccharides degraded by alginate lyase from Vibro sp. 510. Carbohydr Res 339: 1475-1481, 2004

17. Zhang Z, Yu G, Zhao X, Liu H, Guan H, Lawson AM and Chai W: Sequence analysis of alginate-derived oligosaccharides by negative-ion electrospray tandem mass spectrometry. J Am Soc Mass Spectrom 17: 621-630, 2006.

18. Zhang D, Fujii I, Lin C, Ito K, Guan H, Zhao J, Shinohara M and Matsukura M: The stimulatory activities of polysaccharide compounds derived from algae extracts on insulin secretion in vitro. Biol Pharm Bull 31: 921-924, 2008.

19. Yuan Z, Feng W, Hong J, Zheng Q, Shuai J and Ge Y: p38 MAPK and ERK promote nitric oxide production in cultured human retinal pigmented epithelial cells induced by high concentration glucose. Nitric Oxide 20: 9-15, 2009.

20. Pozarowski P and Darzynkiewicz Z: Analysis of cell cycle by flow cytometry. Methods Mol Biol 281: 301-311, 2004

21. Sakaue-Sawano A, Kurokawa H, Morimura T, Hanyu A, Hama H, Osawa H, Kashiwagi S, Fukami K, Miyata T, Miyoshi H, et al: Visualizing spatiotemporal dynamics of multicellular cell-cycle progression. Cell 132: 487-498, 2008.

22. Roccio M, Hahnewald S, Perny M and Senn P: Cell cycle reactivation of cochlear progenitor cells in neonatal FUCCI mice by a GSK3 small molecule inhibitor. Sci Rep 5: 17886, 2015

23. Falk W, Goodwin RH Jr and Leonard EJ: A 48-well micro chemotaxis assembly for rapid and accurate measurement of leukocyte migration. J Immunol Methods 33: 239-247, 1980.

24. Livak KJ and Schmittgen TD: Analysis of relative gene expression data using real-time quantitative PCR and the 2(-Delta Delta $\mathrm{C}(\mathrm{T})$ ) method. Methods 25: 402-408, 2001.

25. Guo L, Ning W, Tan Z, Gong Z and Li X: Mechanism of matrix metalloproteinase axis-induced neointimal growth. J Mol Cell Cardiol 66: 116-125, 2014.

26. Sasaki A, Arawaka S, Sato H and Kato T: Sensitive western blotting for detection of endogenous Ser129-phosphorylated $\alpha$-synuclein in intracellular and extracellular spaces. Sci Rep 5: 14211, 2015.

27. Krieg RC, Dong Y, Schwamborn K and Knuechel R: Protein quantification and its tolerance for different interfering reagents using the BCA-method with regard to 2D SDS PAGE. J Biochem Biophys Methods 65: 13-19, 2005.

28. Lacroix M, Abi-Said D, Fourney DR, Gokaslan ZL, Shi W, DeMonte F, Lang FF, McCutcheon IE, Hassenbusch SJ, Holland E, et al: A multivariate analysis of 416 patients with glioblastoma multiforme: Prognosis, extent of resection, and survival. J Neurosurg 95: 190-198, 2001.

29. Messaoudi K, Clavreul A and Lagarce F: Toward an effective strategy in glioblastoma treatment. Part I: Resistance mechanisms and strategies to overcome resistance of glioblastoma to temozolomide. Drug Discov Today 20: 899-905, 2015.

30. Ho JW, Leung YK and Chan CP: Herbal medicine in the treatment of cancer. Curr Med Chem Anticancer Agents 2: 209-214, 2002.

31. Cooper WA, Kohonen-Corish MR, Zhuang L, McCaughan B, Kennedy C, Screaton G, Sutherland RL and Lee CS: Role and prognostic significance of tumor necrosis factor-related apoptosis-inducing ligand death receptor DR5 in nonsmall-cell lung cancer and precursor lesions. Cancer 113: 135-142, 2008.

32. Gamet-Payrastre L, Li P, Lumeau S, Cassar G, Dupont MA, Chevolleau S, Gasc N, Tulliez J and Tercé F: Sulforaphane, a naturally occurring isothiocyanate, induces cell cycle arrest and apoptosis in HT29 human colon cancer cells. Cancer Res 60: 1426-1433, 2000.

33. Drexler HG: Review of alterations of the cyclin-dependent kinase inhibitor INK4 family genes p15, p16, p18 and p19 in human leukemia-lymphoma cells. Leukemia 12: 845-859, 1998.

34. Snoek BC, de Wilt LH, Jansen G and Peters GJ: Role of E3 ubiquitin ligases in lung cancer. World J Clin Oncol 4: 58-69, 2013. 
35. Terasima T and Tolmach LJ: Changes in X-ray sensitivity of HeLa cells during the division cycle. Nature 190: 1210-1211, 1961.

36. Terasima $\mathrm{T}$ and Tolmach LJ: Growth and nucleic acid synthesis in synchronously dividing populations of HeLa cells. Exp Cell Res 30: 344-362, 1963.

37. Johnson GL, Dohlman HG and Graves LM: MAPK kinase kinases (MKKKs) as a target class for small-molecule inhibition to modulate signaling networks and gene expression. Curr Opin Chem Biol 9: 325-331, 2005.

38. Tesh VL: Activation of cell stress response pathways by Shiga toxins. Cell Microbiol 14: 1-9, 2012

39. An HK, Kim KS, Lee JW, Park MH, Moon HI, Park SJ, Baik JS, $\mathrm{Kim} \mathrm{CH}$ and Lee YC: Mimulone-induced autophagy through p53-mediated AMPK/mTOR pathway increases caspase-mediated apoptotic cell death in A549 human lung cancer cells. PLoS One 9: e114607, 2014.

40. Lane DP: Cancer. p53, guardian of the genome. Nature 358: 15-16, 1992.
41. Wang Q, Su L, Liu N, Zhang L, Xu W and Fang H: Cyclin dependent kinase 1 inhibitors: A review of recent progress. Curr Med Chem 18: 2025-2043, 2011.

42. Lee K, Hart MR, Briehl MM, Mazar AP and Tome ME: The copper chelator ATN-224 induces caspase-independent cell death in diffuse large B cell lymphoma. Int J Oncol 45: 439-447, 2014.

43. Odagiri H, Kadomatsu T, Endo M, Masuda T, Morioka MS, Fukuhara S, Miyamoto T, Kobayashi E, Miyata K, Aoi J, et al: The secreted protein ANGPTL2 promotes metastasis of osteosarcoma cells through integrin $\alpha 5 \beta 1$, p38 MAPK, and matrix metalloproteinases. Sci Signal 7: ra7, 2014.

44. Kessenbrock K, Plaks V and Werb Z: Matrix metalloproteinases: Regulators of the tumor microenvironment. Cell 141: 52-67, 2010.

(1) (9) This work is licensed under a Creative Commons Attribution-NonCommercial-NoDerivatives 4.0 International (CC BY-NC-ND 4.0) License. 